\title{
An activated carbon monolith as an electrode material for
}

\section{supercapacitors}

\author{
V. Ruiz ${ }^{1},{ }^{*}$ C. Blanco ${ }^{1}$, R. Santamaría ${ }^{1}$ J.M. Ramos-Fernández ${ }^{2}$, M. Martínez- \\ Escandell $^{2}$, A. Sepúlveda-Escribano ${ }^{2}$, F. Rodríguez-Reinoso ${ }^{2}$ \\ ${ }^{1}$ Instituto Nacional del Carbón, CSIC, Apdo. 73, 33080, Oviedo, Spain \\ ${ }^{2}$ Dept. Química Inorgánica, Universidad de Alicante, Apdo. 99, E-3080, Alicante, Spain
}

\begin{abstract}
.-
Activated carbon binderless monoliths with high consistency and large porosity, synthesised from a mesophase pitch, are studied as electrodes for supercapacitors. The electrochemical cells prepared provided high capacitance values in sulphuric acid media $\left(334 \mathrm{~F} \mathrm{~g}^{-1}\right)$ and very low electrical resistivity, which results in a very efficient energy storage device (12 $\mathrm{Wh} \mathrm{Kg}^{-1}$ maximum energy density and $12,000 \mathrm{~W} \mathrm{Kg}^{-1}$ maximum power density). Long-term cycling experiments showed excellent stability with a reduction of the initial capacitance values of $19 \%$ after performing 23,000 galvanostatic cycles at $\sim 300 \mathrm{~mA} \mathrm{~g}^{-1}$.
\end{abstract}

\footnotetext{
* Corresponding author: clara@incar.csic.es; Tel. + 349851190 90; Fax: + 34985297662
} 


\section{1.- Introduction}

Supercapacitors (SCs) are an important alternative or complement to other energy storage or generation devices such as secondary batteries and fuel cells [1], as they can develop longer cycle life (> 100,000 cycles) combining both high power density (> 1000-1500 $\mathrm{W} \mathrm{Kg}^{-1}$ ) and energy density values (up to $10 \mathrm{Wh} \mathrm{Kg}^{-1}$ ) [2,3]. These particular properties make supercapacitors suitable for numerous applications such as power electronics, military field, and in the hybrid electrical vehicle (HEV) (e.g. stop and go function, improved acceleration, regenerative braking, etc.).

Among the materials that can be used as electrode in supercapacitors (e.g. electroactive polymers [4], transition-metal oxides [5], etc.) carbon materials have demonstrated to be ideal candidates as a consequence of their relatively low cost, good electronic conductivity, high surface area and availability [6]. In fact, several carbonbased devices are commercially available (Epcos, Maxwell, Evans, etc.). Activated carbons are commonly employed as they are very attractive from the economical point of view [6]. In this type of materials the charge is stored by means of electrostatic charge separation of ions at the interface electrode/electrolyte forming the so-called double layer.

Activated carbon can be prepared from any carbonaceous precursor by physical or chemical activation. Chemical activation with $\mathrm{KOH}$ or $\mathrm{NaOH}$ is a good method to produce activated carbons $[7,8]$, usually in the form of fine powder, thus making its conforming to pellets or monoliths an important area of research. The manufacture of electrodes for supercapacitors requires the addition of a binder (e.g. polyvynilidene chloride (PVDC) [9], Teflon [10], etc.), in proportions that usually vary from 5 to 10 wt. $\%$ in order to bind the carbon particles together. However, this addition blocks 
part of the porosity of the carbon [11,12] and additionally causes an increase in electrical resistivity $[13,14]$. Consequently, the use of binderless electrodes in supercapacitors would provide significant benefits: they can be handled easily compared to the conventional porous carbons (e.g. activated carbons or carbon nanotubes) and they do not require any conductive additive such as carbon black during the preparation of the electrode.

Some monolithic structures (e.g. aerogeles [15,16], templates from silica monoliths [17], or ceramic-carbon composites [18]) have been used in electrochemical applications (e.g. EDLCs, electrosorptive processes such as capacitative deionization $[19,20]$, etc.) where high surface area and electrical conductivity are critical properties. However, only rather modest specific capacitance values have been reported. Saliger et al. [15] used carbon aerogels from resorcinol-formaldehyde (apparent surface area 400$560 \mathrm{~m}^{2} \mathrm{~g}^{-1}$ ) as electrode in $30 \%$ sulphuric acid as electrolyte and they reported $\sim 130$ $170 \mathrm{~F} \mathrm{~g}^{-1}$ typical values of this type of materials. Hierarchically mesoporous carbon monoliths have been developed using mesophase pitch as a precursor. Silica monoliths as a template for nanocasting [17] provided poor capacitance values $\left(\sim 8 \mathrm{~F} \mathrm{~g}^{-1}\right)$, which could be increased to $25 \mathrm{~F} \mathrm{~g}^{-1}$ by the addition of polyaniline. Higher capacitance values, up to $200 \mathrm{Fg}^{-1}$, were obtained by same authors using $\beta$-naphtol as precursor of monoliths. In addition to the modest capacitance values reported with the monolithic materials, their synthesis is quite expensive (e.g. supercritical drying step in aerogeles synthesis) and in some cases risky [16,21], so alternatives are needed.

Studies using chemical activation of olive stones by $\mathrm{H}_{3} \mathrm{PO}_{4}$ and $\mathrm{ZnCl}_{2}$ as impregnating agents showed that it is possible to prepare highly porous binderless activated carbon monoliths by just introducing the impregnated mass into a cylindrical mould and applying heat and pressure before heat treatment [22,23]. However, the 
electrochemical properties of this type of monolith have not, to our knowledge, been reported yet, probably as a consequence of poor electrical conductivity.

Promising monoliths obtained from mesophase-based materials were recently developed [24] taking profit from their self-sintering ability. These binderless materials seem to be very attractive precursors to be used in supercapacitors, making up the novelty of the present work.

This paper reports the use of microporous activated carbon binderless monoliths (ACM) with high consistency and large porosity synthesised from mesophase pitch (MP) as electrode precursor in electrochemical capacitors.

\section{2.- Experimental}

\section{1.-Carbon-based Monoliths preparation.-}

A petroleum residue (ethylene-tar) [25] was pyrolyzed in a laboratory pilot plant at $440{ }^{\circ} \mathrm{C}$ and a pressure of $1.0 \mathrm{MPa}$, using a heating rate of $10{ }^{\circ} \mathrm{C} / \mathrm{min}$ and a soak time of $4 \mathrm{~h}$ to yield MP [26]. Detailed description of the procedure was reported elsewhere [24]. The synthesis of the ACMs involved several steps: (i) mixture of the MP with $\mathrm{KOH}$ in different proportions in a ball mill during $30 \mathrm{~min}$; (ii) uniaxial conforming at room temperature to produce monoliths $(\Phi=13 \mathrm{~mm} ; 1 \mathrm{~mm})$, conforming under pressure of 400 MPa (the mixture of the carbon precursors and the activating agent can be consolidated because of its high plasticity); (iii) heat treatment at $800{ }^{\circ} \mathrm{C}$ under nitrogen atmosphere, heating rate of $2^{\circ} \mathrm{C} \min ^{-1}$ and soak time of $2 \mathrm{~h}$; and (iv) washing of monoliths with a solution of $1 \mathrm{M} \mathrm{HCl}$, followed by extensive washing with distilled water until $\mathrm{pH} 7$. The final step consists on drying of the monolith at $100-110^{\circ} \mathrm{C}$ for $24 \mathrm{~h}$. Three different 
monoliths (ACM-A, ACM-B and ACM-C) were prepared using $\mathrm{KOH}$ to MP ratios of $4: 1,2: 1$ and $1: 1$, respectively.

\section{2.-Activated carbon and electrode preparation.-}

In order to compare with monolith $\mathrm{ACM}-\mathrm{B}$, a powdered activated carbon (AC-B) was prepared using the same $\mathrm{MP}$ and $\mathrm{KOH}$ ratio. In this case the elaboration of electrodes required the conventional addition of a binding polymer (10 \% wt. PVDF).

\section{3.- ACMs characterization.-}

The ACMs were characterized by adsorption of $\mathrm{N}_{2}$ at $77 \mathrm{~K}$. The apparent or equivalent BET area was determined from the $\mathrm{N}_{2}$-adsorption isotherm using the BET equation. The Dubinin-Radushkevich (DR) equation was applied to the isotherms to obtain the total micropore volume $\left(\mathrm{V}_{0}\right)$ [27]. The volume of mesopores was obtained by difference between the volume measured at $\mathrm{P} / \mathrm{P}_{0}=0.95$ and $\mathrm{V}_{0}$. The pore width $\left(\mathrm{L}_{0}\right)$ was calculated from pore size distribution curves obtained using DFT calculations.

The electrochemical properties of the monoliths (ACMs) were tested using a Swagelok ${ }^{\circledR}$-type cell in a two electrode configuration using a glassy fibrous separator and gold current collectors. Tests were performed in $1 \mathrm{M} \mathrm{H}_{2} \mathrm{SO}_{4}$. Galvanostatic cycling of the supercapacitors was carried out in the voltage window between 0 and $1 \mathrm{~V}$ at current densities of 0.88 to $88 \mathrm{~mA} \mathrm{~cm}^{-2}\left(50-5,000 \mathrm{~mA} \mathrm{~g}^{-1}\right)$ using a Biologic VMP multichannel potenciostat. The capacitance of the system was obtained applying the following equation: $\mathrm{C}_{\text {capacitor }}(\mathrm{F})=\mathrm{I} /(\mathrm{dV} / \mathrm{dt}$ ) (avoiding the ohmic drop). In a twoelectrode system, the lower capacitance value of the two electrodes connected in series will give the total capacitance in accordance with the formula: $1 / C_{\text {capacitor }}=1 / C_{1}+1 / C_{2}$. Assuming that $\mathrm{C}_{1}=\mathrm{C}_{2}$ the specific capacitance of the electrode, $\mathrm{C}\left(\mathrm{F} \mathrm{g} \mathrm{g}^{-1}\right)$, can be obtained from the expression: $\mathrm{C}=2 \mathrm{C}_{\text {capacitor }} / \mathrm{m}$ ( $\mathrm{m}$ is the mass of activated carbon in the lightest electrode). 
The equivalent series resistance (ESR) was calculated from the galvanostatic cylces by dividing the ohmic drop by the current intensity, $\operatorname{ESR}(\Omega)=\operatorname{IR}_{\text {drop }}(\mathrm{V}) / \mathrm{I}(\mathrm{A})$. Cyclic voltammetry experiments were carried out at 1 and $50 \mathrm{mV} \mathrm{s}^{-1}$. Electrochemical impedance spectroscopy measurements were carried out in order to study the internal resistance of the carbon-based monoliths in the frequency range of $1 \mathrm{mHz}-100 \mathrm{kHz}$ with an $\mathrm{AC}$ amplitude of $\pm 10 \mathrm{mV}$. All impedance measurements were performed on completely discharged cells. The Ragone plots were obtained from the galvanostatic experiments (constant current mode).

Long-term behavior of the cells was studied by galvanostatic cycling at a current load of $500 \mathrm{~mA} \mathrm{~g}^{-1}$ and $1 \mathrm{~V}$. The effect of cycling on the specific capacitance values was assessed.

The amount and type of oxygenated surface groups were determined by temperature-programmed decomposition (TPD) under inert atmosphere (He). The sample $(150 \mathrm{mg})$ was placed in a U-shaped quartz cell and treated at $100{ }^{\circ} \mathrm{C}$ for $1 \mathrm{~h}$ under a $\mathrm{He}$ flow of $50 \mathrm{ml} \mathrm{min}$. Then, the temperature was raised at $10^{\circ} \mathrm{C} \mathrm{min}^{-1}$ to $1000^{\circ} \mathrm{C}$. On-line mass spectrometry was used to measure the decomposition products $\left(\mathrm{CO}\right.$ and $\left.\mathrm{CO}_{2}\right)$.

\section{3.- Results and discussion}

\section{1.-Textural and chemical characteristics of the ACMs.-}

The $\mathrm{N}_{2}(77 \mathrm{~K})$ adsorption isotherms for the three electrode materials (Figure 1) are type I, with a well defined plateau, indicating that the materials are essentially microporous. The broadening of the knee in the very low relative pressures range 
indicates that the microporosity of the material becomes wider upon increasing $\mathrm{KOH} / \mathrm{MP}$ ratio, especially for sample ACM-A.

Table 1 summarizes the textural properties of the ACMs. The apparent BET area was obtained applying the BET equation to the corresponding isotherm. ACM-A has the highest BET surface $\left(2650 \mathrm{~m}^{2} \mathrm{~g}^{-1}\right)$, and a total pore volume measured at $\mathrm{P} / \mathrm{P}_{0}=0.95$ of $1.27 \mathrm{~cm}^{3} \mathrm{~g}^{-1}$, most of the pores being micropores $(73 \%)$, with an average pore width of $1.12 \mathrm{~nm}$. On the other hand, ACM-C exhibits the lowest BET surface $\left(400 \mathrm{~m}^{2} \mathrm{~g}^{-1}\right)$, with a much lower mesopore volume $\left(0.03 \mathrm{~cm}^{3} \mathrm{~g}^{-1}\right)$ and a narrower pore width $(0.86 \mathrm{~nm})$, being almost exclusively microporous. ACM-B is more similar to ACM-C, but with slightly larger BET surface $\left(1100 \mathrm{~m}^{2} \mathrm{~g}^{-1}\right)$ and larger pore volume $\left(0.49 \mathrm{~cm}^{3} \mathrm{~g}^{-1}\right)$.

The analysis of the microstructure of a transversal section of the monolith by SEM (Figure 2) reveals a continuous mass with no grain boundaries. The existence of voids of several microns, which may have formed in the original boundaries of the MP grains with $\mathrm{KOH}$ particles, can clearly be observed. In this way, the sample has a large amount of microporosity, with high accessibility due to the interparticle voids.

The amount and type of oxygen surface groups were determined by temperatureprogrammed decomposition (TPD). All samples have very similar desorption amounts of $\mathrm{CO}$ and $\mathrm{CO}_{2}$ produced upon heat-treatment, values being: $[\mathrm{CO}]=0.453 \mathrm{mmol} \mathrm{g}^{-1}$, $\left[\mathrm{CO}_{2}\right]=0.078 \mathrm{mmol} \mathrm{g}^{-1}$ for ACM-B. Therefore, the differences in electrochemical behaviour of the samples would mainly result from their textural parameters, as functionalities may affect in the same way to all the samples.

\section{2.-Electrochemical characteristics of the ACMs.-}

Figure 3 shows the dependence of the specific capacitance values with the current density measured for the three ACMs synthesized. The higher capacitance values correspond to sample ACM-A, which correlates with its higher surface area (see 
Table 1), followed by sample ACM-B, and the lowest capacitance values are those obtained for sample ACM-C. For example, at the lowest current density measured (1 $\mathrm{mA})$ the specific capacitance values obtained for ACM-A are as high as $334 \mathrm{~F} \mathrm{~g}^{-1}$.

In order to study the resistance of the electrochemical cells prepared, impedance spectroscopy measurements were performed (Figure 4.a). The knee frequency appears at $\sim 150 \mathrm{mHz}$, value that separates the capacitative behavior of the capacitor (vertical line, at low frequencies [28]) from the resistive one (at high frequencies). At high frequencies, the imaginary part of the impedance tends towards zero and the resistance measured is related to the ionic resistance of the electrolyte. In the mid-frequency range, the cell behaves as a combination of resistor and capacitor, where the electrode porosity and thickness play a vital role in the determination of capacitance values [29]. In the range of medium-high frequencies no semicircle can be observed for any of the ACMs. The absence of this loop indicates that the materials have a really low intrinsic resistance. Additionally, the Warburg-like behaviour of the spectra indicates that there is a good electrolyte penetration in the porous structure of the bulk electrode (RC network distribution [30]). This is also reflected in the low ESR values obtained for the three samples: $\sim 0.6 \Omega \mathrm{cm}^{2}$. These low ESR values make these monolithic materials very attractive for the application under study.

For comparison purposes, a supercapacitor was assembled with the conventional carbon/polymer composite (AC-B) using the same electrolyte. The impedance spectra of the conventional composite and that corresponding to the monolithic electrode (ACM-B) are shown in Figure 4b. Contrary to the behaviour displayed by the monoliths, the carbon/polymer composite shows a well defined semicircle loop in the region of medium-high frequencies $(\sim 21 \mathrm{kHz}-128 \mathrm{~Hz})$. This indicates a high intrinsic resistance of the electrode material, decreasing the performance of the cell in terms of 
resistance and power. In this case the presence of polymer in the electrode makes the global resistance of the cell to be higher. An additional advantage of the monolith material for this application is its higher density in comparison with the electrode prepared using a binder. The bulk density of ACM-B is $0.5 \mathrm{~g} / \mathrm{cm} 3$, significantly higher than that of $\mathrm{AC}-\mathrm{B}(0.35 \mathrm{~g} / \mathrm{cm} 3)$.

The Ragone plots (Figure 5) summarise the power and energy characteristics of the electrochemical capacitors assembled. The graphs show the typical behaviour, with steady values of energy density at low power density values, to then drop very rapidly with increasing power density. The values of specific energy are higher for sample ACM-A, followed by sample ACM-B and the smaller ones correspond to sample ACM$\mathrm{C}$, in accordance to their lower capacitance values. Very efficient energy storage devices are obtained using sample ACM-A, with $12 \mathrm{Wh} \mathrm{Kg}^{-1}$ of maximum energy and $12,000 \mathrm{~W} \mathrm{Kg}^{-1}$ of maximum power density in the voltage range of $1 \mathrm{~V}$.

The behaviour of ACM-A during long-term cycling is shown in Figure 6. The reduction in the initial specific capacitance values was estimated in $19 \%$ after 23,000 galvanostatic cycles, from 279 to $226 \mathrm{~F} \mathrm{~g}^{-1}$. It has also to be mentioned that the main capacitance fading occurs in the beginning of cycling, during the first 3,500 cycles. Then the capacitance values remain practically constant during the rest of the test. This can be attributed to the existence of irreversible reactions at the beginning of the prolonged cycling (e.g. electro-oxidation) after which the values tend to stabilize. The cyclic voltammograms corresponding to the same electrochemical cell obtained in the first and $23,000^{\text {th }}$ cycles are shown in Figure 6 b. For both voltammograms the rectangular shape typical of electrical double layer capacitors was found. The main alteration in the shape of the cycle is the reduction in the current intensity during the anodic sweep, an effect generally ascribed to carbon oxidation [31]. As described 
elsewhere $[32,33]$ this oxidative phenomenon is more pronounced in the positive electrode, whereas the negative electrode hardly changes its performance during longterm cycling.

\section{4.- Conclusions}

Novel binderless monolithic materials prepared from a self-sintering mesofasebased precursor showed an excellent performance as electrodes in high-power supercapacitors. The behavior of these monoliths is significantly better than the conventional active material/polymer composite electrodes, as a result of their improved electrical conductivity (due to the absence of binder) and their highly accessible micropores (due to the presence of interparticle voids).

Very high capacitance values were obtained $\left(334 \mathrm{~F} \mathrm{~g}^{-1}\right)$ with highest surface are monolith ACM-A. Moreover, this sample provided very efficient energy storage devices, with $12 \mathrm{Wh} \mathrm{Kg}^{-1}$ of maximum energy density and $12,000 \mathrm{~W} \mathrm{Kg}^{-1}$ of maximum power density in the voltage range of $1 \mathrm{~V}$.

Long-term cycling experiments performed on ACMs show an excellent behavior, with a total loss of the initial capacitance values of $19 \%$ after 23,000 galvanostatic charge-discharge cycles, which mainly occurred during the first 3,500 cycles.

Acknowledgements.- This work has been performed with financial support from MEC (projects MAT2007-61467 and MAT2007-61734). V. Ruiz acknowledges a predoctoral research grant from FICYT. 


\section{References}

[1] Kötz R, Carlen M. Principles and applications of electrochemical capacitors Electrochim Acta 2000; 45(15-16): 2483-98.

[2] Conway BE. Electrochemical Supercapacitors, Scientific Fundamentals and Technological Applications. New York: Kluwer Academic/Plenum Publishers; 1999: $11-31$.

[3] Burke A. Ultracapacitors: Why, how, and where is the technology. J Power Sources 2000; 91(1): 37-50.

[4] Arbizzani C, Gallazzi MC, Mastragostino M, Rossi M, Soavi F. Capacitance and cycling stability of poly(alkoxythiophene) derivative electrodes. Electrochem Commun 2001; 3(1): 16-19.

[5] Choi D, Blomgren GE, Kumta PN. Fast and reversible surface redox reaction in nanocrystalline vanadium nitride supercapacitors. Adv Mater 2006; 18(9): 1178-82.

[6] Frackowiak E, Béguin F. Carbon materials for the electrochemical storage of energy in capacitors. Carbon 2001; 39 (9): 937-950.

[7] Marsh H, Yan DS, O'Grady TM, Wenneberg A. formation of active carbons from cokes using potassium hydroxide. Carbon 1984; 22 (6): 603-611.

[8] Berger D, Carton B, Métrot A. Interaction of potassium and sodium with carbons. In: Trower PA, Walker Jr PL, editors. Chemistry and Physics of Carbon, vol 12. New York: Marcel Dekker; 1975; p. 1-36.

[9] An KH, Kim WS, Park YS, Choi YC, Lee SM, Chung DC et al. Supercapacitors using single-walled carbon nanotube electrodes. Adv Mater 2001; 13(21): 497-500.

[10] Shiraishi S, Kurihara H, Oya A. Preparation and electric double layer capacitance of mesoporous carbon. Carbon Science 2001; 1(3-4): 133-137. 
[11] Ruiz V, Blanco C, Granda M, Menéndez R, Santamaría R. Influence of electrode preparation on the electrochemical behaviour of carbon-based supercapacitors. J Appl Electrochem 2007; 37: 717-721.

[12] Yoon SY, Lee J, Hyeon T, Oh SM. Electric double-layer capacitor performance of a new mesoporous carbon. J Electrochem Soc 2000; 147 (7): 2507-2512.

[13] Weng TC, Teng H. Characterization of High Porosity Carbon Electrodes Derived from Mesophase Pitch for Electric Double-Layer Capacitors. J Electrochem Soc 2001; 148: A368-A373.

[14] Gamby J, Taberna PL, Simon P, Fauvarque JF, Chesneau M. Studies and characterisations of various activated carbons used for carbon/carbon supercapacitors. J Power Sources 2001; 101(1): 109-116.

[15] Saliger R, Fischer U, Herta C, Fricke J. High surface area carbon aerogels for supercapacitors. J Non-Cryst Solids 1998; 225: 81-85.

[16] Hebalkar N, Arabale G, Sainkar SR, Pradhan SD, Mulla IS, Vijayamohanan K, et al. Study of correlation of structural and surface properties with electrochemical behaviour in carbon aerogels. J Mater Sci 2005 ; 40: 3777-3782.

[17] Fan LZ, Hu YS, Maier J, Adelhelm P, Smarsly B, Antonietti M. High electroactivity of polyaniline in supercapacitors by using a hierarchically porous carbon monolith as a support. Adv Funct Mater 2007; 17: 3083-3087.

[18] Kosmulski M, Skubiszewska-Zieba J, Leboda R, Marczewska-Boczkowska K, Próchniak P. New ceramic-carbon composites for electrodes for electrochemical capacitors. J Colloid Interface Sci 2007; 309: 160-168.

[19] Farmer JC, Fix DV, Mack GV, Pekala RW, Poco JF. Capacitive deionization of $\mathrm{NaCl}$ and $\mathrm{NaNO}_{3}$ solutions with carbon aerogel electrodes. J Electrochem Soc 1996; 143 (1): 159-169. 
[20] Farmer JC, Fix DV, Mack GV, Pekala RW, Poco JF. Capacitive deionization of $\mathrm{NH}_{4} \mathrm{ClO}_{4}$ solutions with carbon aerogel electrodes. J of ApplElectrochem 1996; 26 (10): 1007-1018.

[21] Lemay JD, Hopper RW, Hrubesh LW, Pekala RW. Low-density microcellular material. MRS Bull. 15 (1990) 19-20.

[22] Molina-Sabio M, Rodríguez-Reinoso F. Role of chemical activation in the development of carbon porosity. Colloid Surf A-Physicochem Eng Asp 2004; 241 (1-3): $15-25$.

[23] Molina-Sabio M, Almansa C, Rodríguez-Reinoso F. Phosphoric acid activated carbon discs for methane adsorption. Carbon 2003: 41(11): 2113-2119.

[24] Ramos-Fernández JM, Martínez-Escandell M, Rodríguez-Reinoso F. Production of binderless activated carbon monoliths by $\mathrm{KOH}$ activation of carbon mesophase materials. Carbon 2008; 46(2): 384-386.

[25] Torregosa-Rodríguez P, Martínez-Escandell M, Rodríguez-Reinoso F, Marsh H, Gómez de Salazar C, Romero Palazón E. Pyrolysis of petroleum residues. II. Chemistry of pyrolysis. Carbon 2000; 38(4): 535-546.

[26] Marsh H, Martínez-Escandell M, Rodríguez-Reinoso F. Semicokes from pitch pyrolysis: mechanisms and kinetics. Carbon 1999; 37(3): 363-390.

[27] Rodríguez-Reinoso F, Garrido J, Martín-Martínez JM, Molina-Sabio M, Torregrosa R. The combined use of different approaches in the characterization of microporous carbons .Carbon 1989; 27(1): 23-32.

[28] De Levie R. On porous electrodes in electrolyte solutions. Electrochim Acta $1963 ; 8: 751-780$ 
[29] Ganesh V, Pitchumani S, Lakashminarayanan V. New symmetric and asymmetric supercapacitors based on high surface area porous nickel and activated carbon. J Power Sources 2006; 158: 1523-1532.

[30] Chen WC, Wen TC, Teng H. Polyaniline-deposited porous carbon electrode for supercapacitor. Electrochim Acta 2003; 48(6): 641-649.

[31] Mitrovic D, Panic V, Dekanski A, Milonjic S, Atanasoski R, Nikolic B. The effect of the composition of the dispersing medium of oxide sols on the electrocatalytic activity of sol-gel obtained $\mathrm{RuO}_{2}-\mathrm{TiO}_{2} / \mathrm{Ti}$ anodes. J Serb Chem Soc 66(11-12) (2001) $847-857$

[32] Zuleta M, Björnbom P, Lundblad A. Effects of pore surface oxidation on electrochemical and mass-transport properties of nanoporous carbon. J Electrochem Soc 2005; 152 (2): A270-A276.

[33] Malmberg H., Ruiz V, Blanco C, Santamaría R, Lundblad A, Björnbom P. An insight into Faradaic phenomena in activated carbon investigated by means of the microelectrode technique. Electrochem Commun 2007; 9(9): 2321-2325. 


\section{Table captions}

Table 1.- Textural characterization of ACMs 


\section{Figure Captions}

Figure 1. $\mathrm{N}_{2}$ Adsorption isotherms at $77 \mathrm{~K}$.

Figure 2.- SEM image of a transversal section of ACM-B monolith.

Figure 3.- Variation of the specific capacitance values with the current density. Current load 50-5000 $\mathrm{mA} \mathrm{g}^{-1}$ and operating voltage $1 \mathrm{~V}$.

Figure 4.- Complex-plane impedance plots for: a) the activated carbon monoliths (ACMs) and b) the conventional carbon/polymer composite (AC-B).

Figure 5.- Ragone plots for the electrochemical cells.

Figure 6.- a) Variation of the specific capacitance values on the number of cycles at a current density of $320 \mathrm{~mA} \mathrm{~g}^{-1}$ and b) cyclic voltammogram performance during cycling. 
Table 1.-

\begin{tabular}{lcccccc}
\hline sample & $\mathrm{Vt} / \mathrm{cm}^{3} \mathrm{~g}^{-1}$ & $\mathrm{~V}_{0} / \mathrm{cm}^{3} \mathrm{~g}^{-1}$ & $\mathrm{~L}_{0} / \mathrm{nm}$ & $\mathrm{S}_{\mathrm{mic}} / \mathrm{m}^{2} \mathrm{~g}^{-1}$ & $\mathrm{~S}_{\mathrm{BET}} / \mathrm{m}^{2} \mathrm{~g}^{-1}$ & $\mathrm{~V}_{\text {meso }} / \mathrm{cm}^{3} \mathrm{~g}^{-1}$ \\
\hline ACM-A & 1.27 & 0.92 & 1.12 & 1830 & 2652 & 0.33 \\
ACM-B & 0.49 & 0.47 & 0.92 & 990 & 1107 & 0.05 \\
ACM-C & 0.20 & 0.17 & 0.86 & 315 & 403 & 0.03
\end{tabular}

$V t$ : total pore volume, $V_{0}$ : total volume of micropores, $L_{0}$ : average pore size, $S_{\text {mic }}:$ microporous surface area, $S_{B E T}$ : apparent BET area, $V_{\text {meso }}$ : volume of mesopores. 
Figure 1.

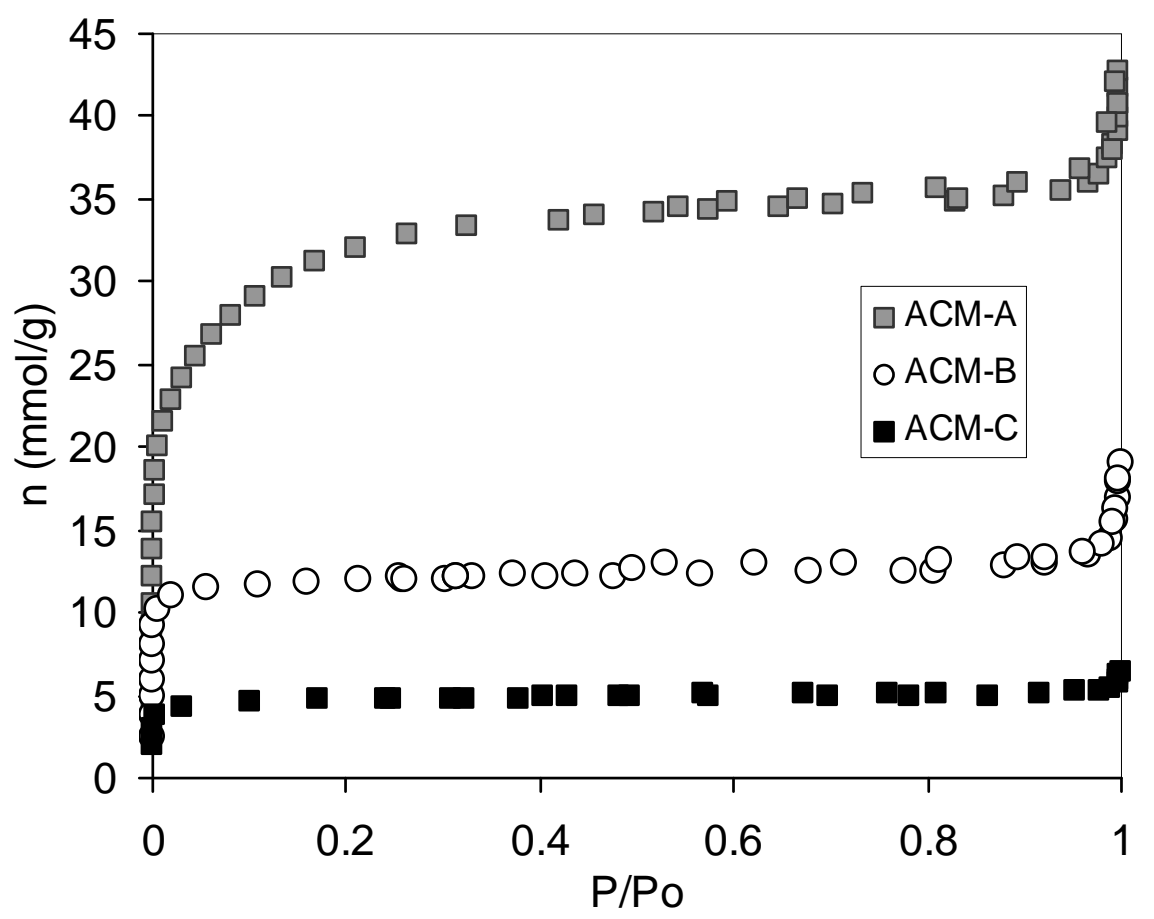


Figure 2

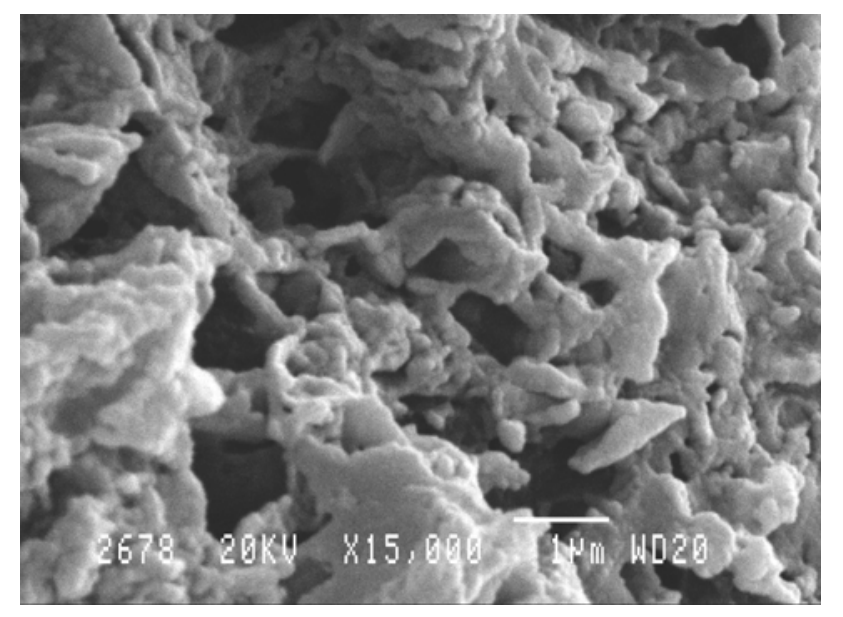


Figure 3

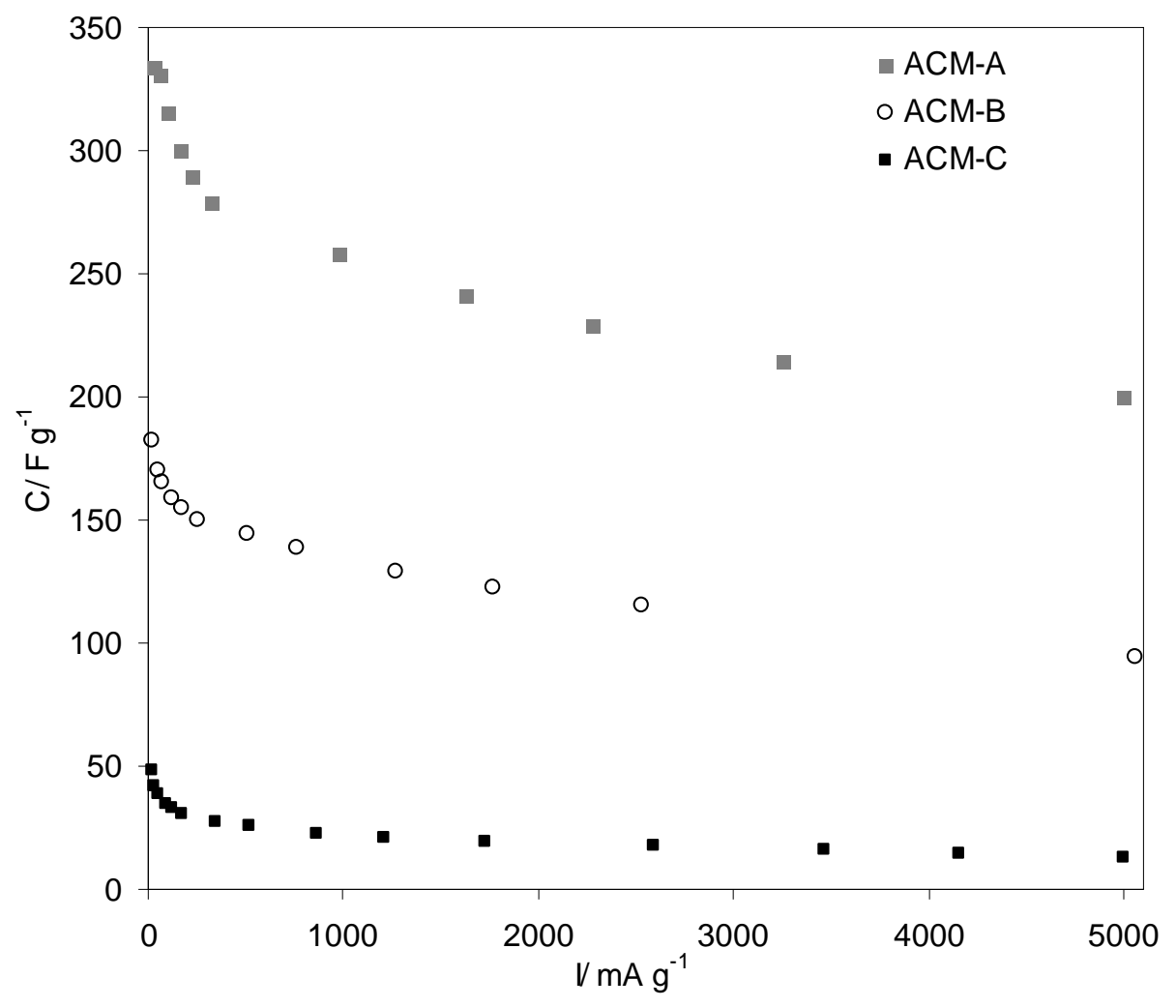


Figure 4

a)

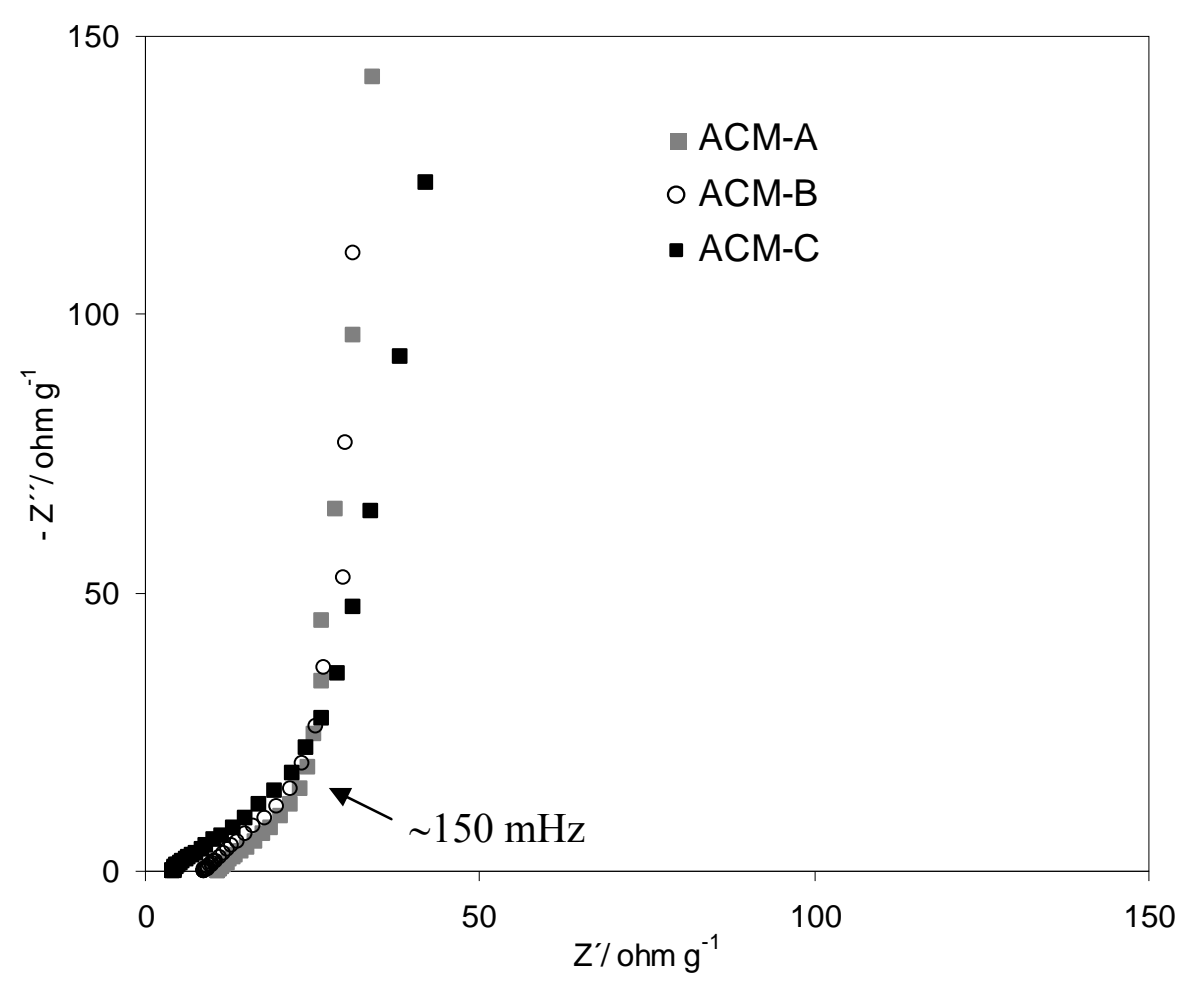

b)

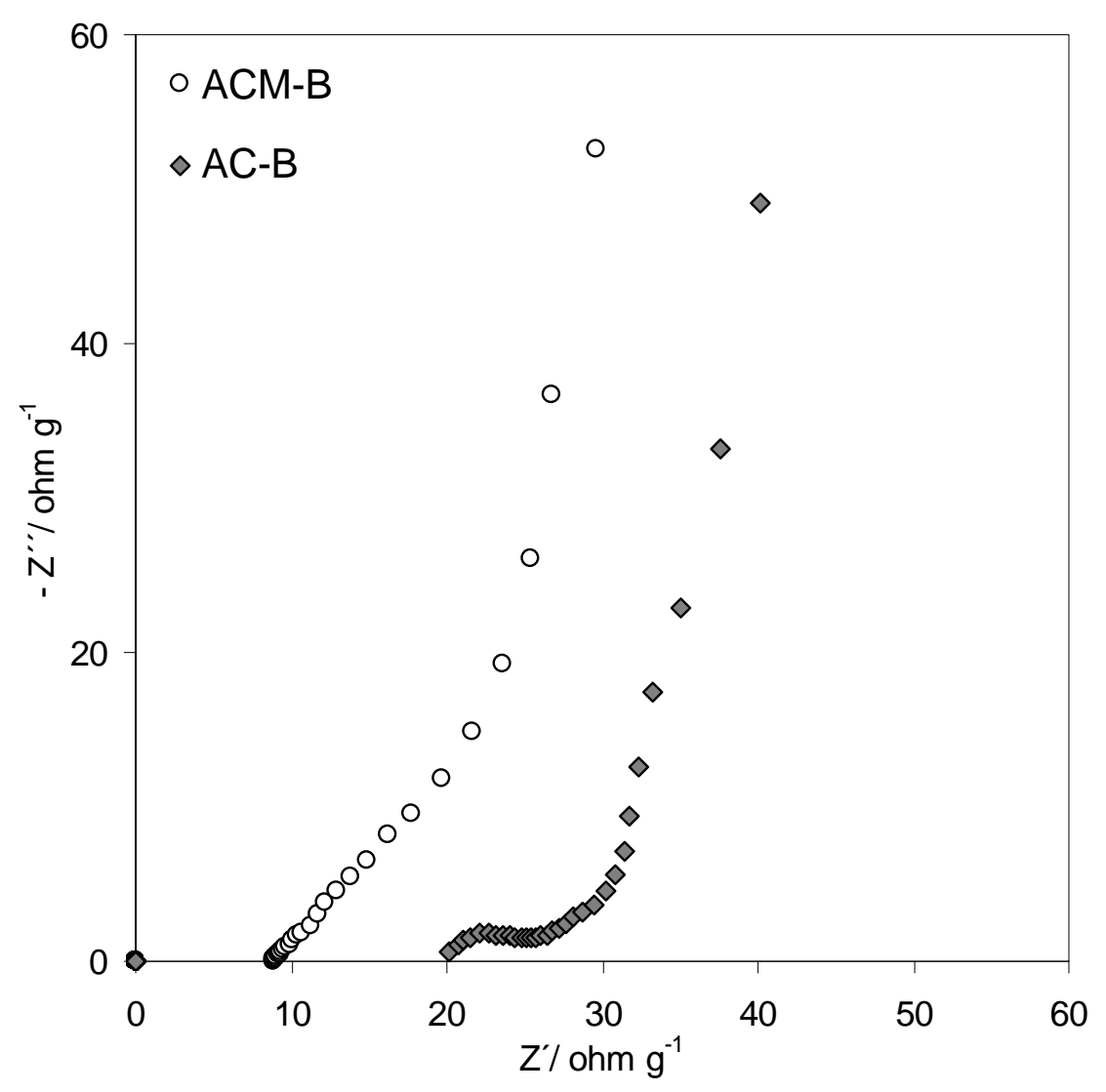


Figure 5

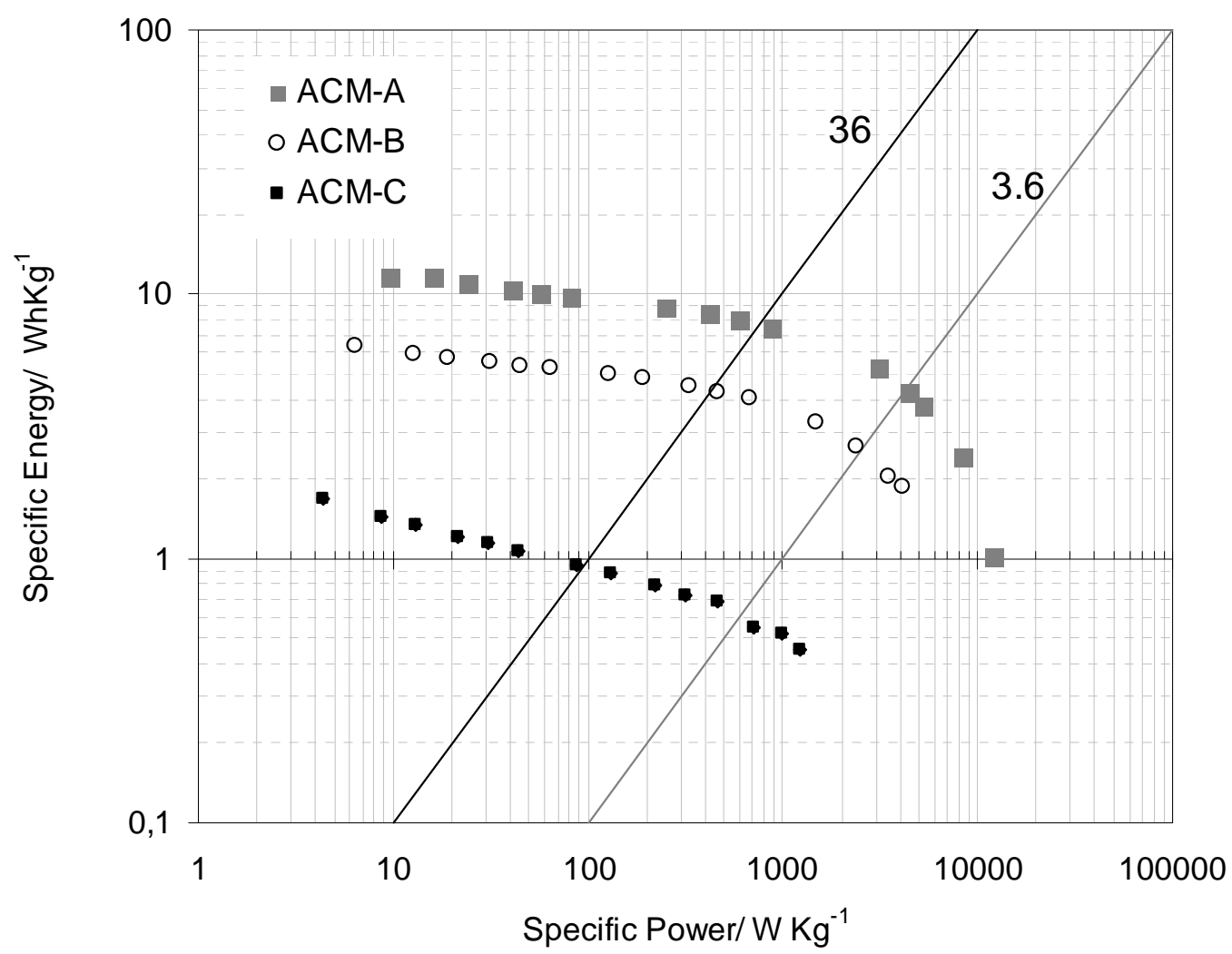




\section{Figure 6}

a)

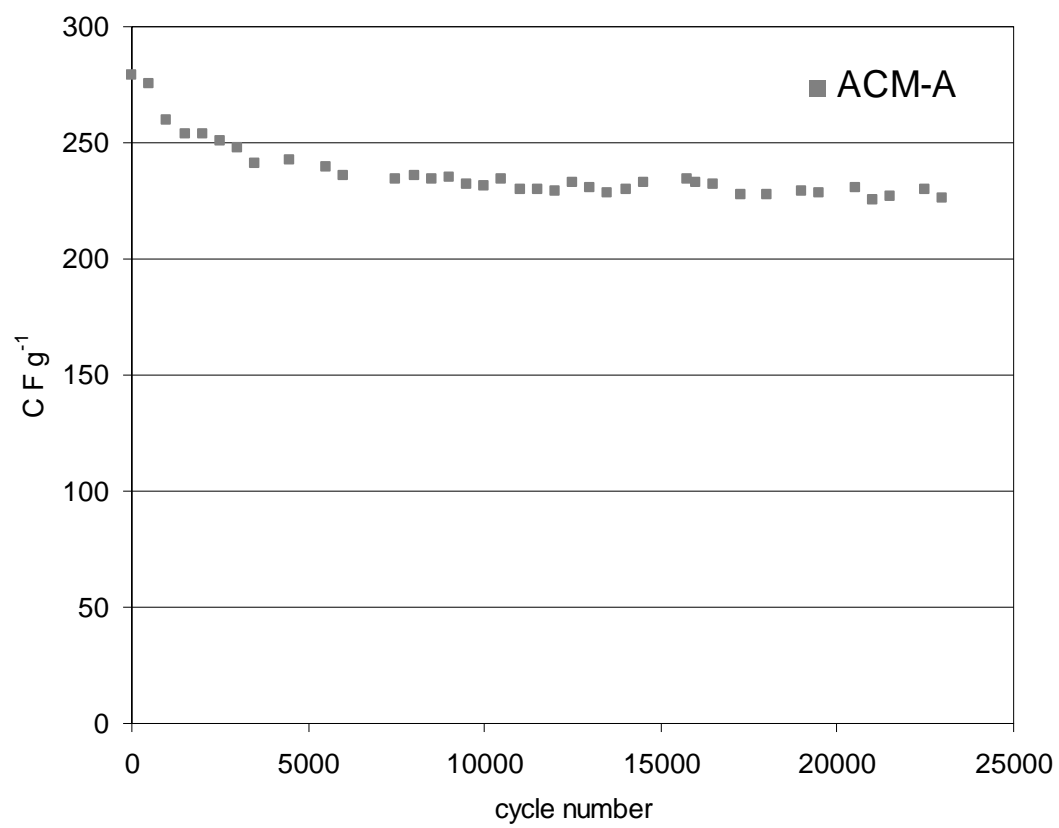

b)

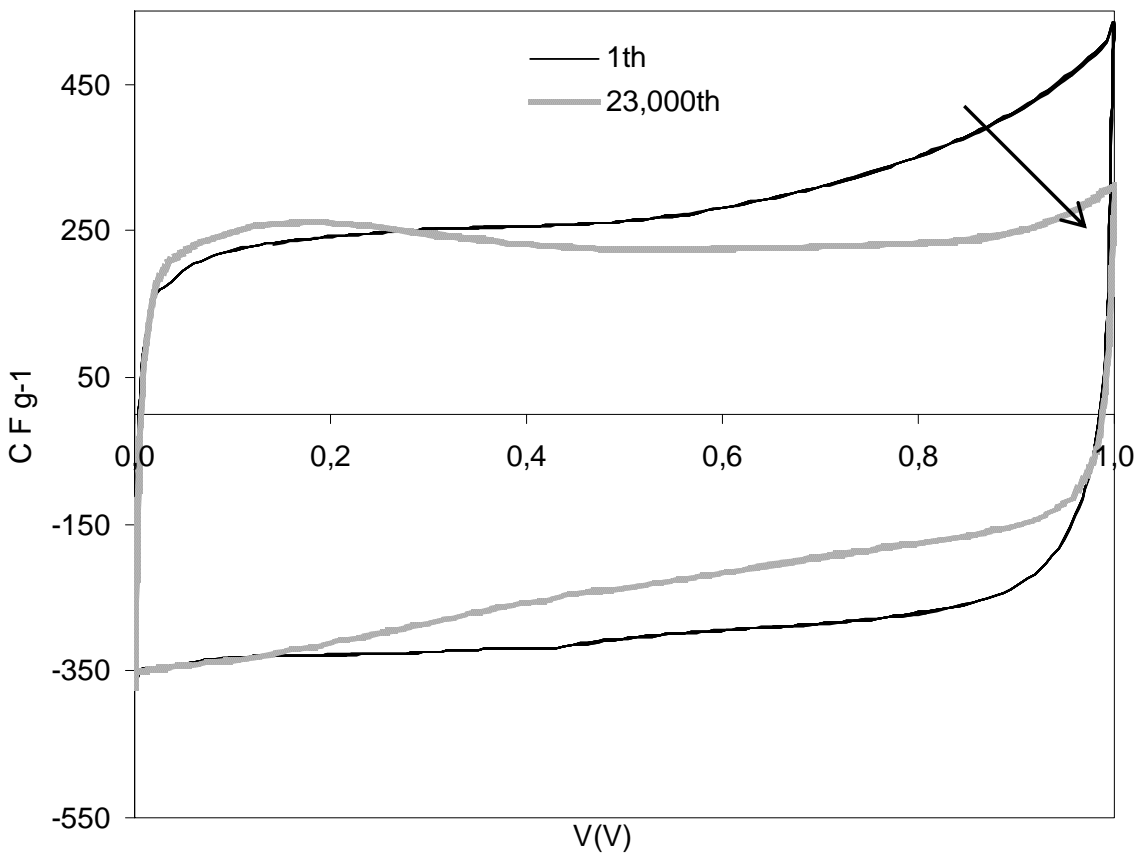

